\title{
AIKUISIÄN KIELIHÄIRIÖIDEN AIVOPERUSTA JA KUNTOUTUS
}

Anu Klippi, Anna-Maija Korpijaakko-Huuhka, Matti Lehtihalmes \& Pirkko Rautakoski (toim.) 2017. Afasia. Aikuisiän kielihäiriöiden aivoperusta ja kuntoutus. Helsinki: Gaudeamus Oy. 443 s. ISBN 978-952-495-440-2

Afasia koskettaa tänä päivänä satojatuhansia aikuisia suomalaisia sekä heidän läheisiään. Afasia on neurologisperäinen kielellinen häiriö, jonka monimuotoisuuden vuoksi sitä on lähestyttävä tutkimuksen näkökulmasta monitieteisesti ja kuntoutuksen näkökulmasta moniammatillisesti. Teoksen kirjoittajina onkin eri tutkimusalojen edustajia ja kliinistä työtä tekeviä puheterapeutteja. Toimittajat ovat suomalaisen logopedian alan pitkän linjan afasian tutkijoita ja kliinikoita. He toteavat esipuheessaan kirjan olevan tarkoitettu hyvin laajan lukijakunnan käyttöön (tutkijat, opiskelijat, ammattilaiset sekä afaattiset ihmiset ja heidän läheisensä), ja näin tehdessään he ottavat itselleen suuren haasteen. Monitieteisen afasiatutkimuksen ja ammatillisen terminologian saaminen sujuvaan suomenkieliseen asuun ei ole helppo tehtävä. Tässä toimittajat ja kirjoittajat onnistuvat hyvin, ja he ovat tehneet suuren työn terminologian suomentamiseksi ja määrittelemiseksi. Lukijaa helpottamaan löytyy kirjan lopusta 16 sivun sanasto, joten teoksen lukeminen onnistuu myös muilta kuin afasian tutkijoilta tai kliinikoilta.

Teos on jaettu neljään päälukuun, joista jokaisen luvun alussa on lyhyt lukijaa orientoiva johdanto. Ensimmäinen pääluku Kieli, kielenkäyttö ja kielihäiriöt käsittelee uusinta afasiaan liittyvää aivotutkimusta sekä afasian ilmenemismuotoja ja niiden vaikutuksia kielelliseen vuorovaikutukseen. Hulténin artik- kelissa tarkastellaan kielen käsittelyä terveissä aivoissa ja siinä käydään läpi tunnetuimmat teoreettiset mallit (mm. Friederici, 2002; Hagoort, 2013; Hickock \& Poeppel, 2007) kielen aivoperustasta sekä puheen tuoton että vastaanoton osalta. Kirjoittaja korostaa hyvin kielen jatkuvaa vuorovaikutussuhdetta muiden mielen toimintojen kanssa; kielellisiin toimintoihin erikoistuneet aivoalueet eivät toimi irrallisina. Lehtihalmeksen artikkelissa tarkastellaan aivopuoliskojen työnjakoa kielellisten toimintojen osalta. On tärkeää, että siinä käsitellään usein vähemmälle huomiolle jäävän oikean aivopuoliskon roolia puheen pragmaattisten piirteiden käsittelyssä ja kerronnassa. Esiintyvyyttä pohditaan määrittelyn näkökulmasta eli pitäisikö muun muassa aivovammoihin sekä eteneviin aivosairauksiin liittyvät kielelliset ongelmat laskea afasian esiintyvyyslukuihin? Jos afasia määriteltäisiin laajemmin kielellisen viestinnän häiriöksi, joka sisältää myös sosiaalisen kielenkäytön ongelmat, afaattisten ihmisten määrä kasvaisi huomattavasti. Tekstissä näkyy hyvin historiallinen jatkumo, perinteisistä afasian oireluokitteluista (Luria, 1973; Goodglass \& Kaplan, 1972) siirrytään moderneihin kognitiivisten toimintojen hermoverkkoteorioihin sekä valkean aineen yhteyksien merkitykseen kielen kannalta. Myös hermoverkon toimintaa muokkaavat yksilönkehitys ja elämänhistoria tuodaan esiin yksilöllisesti vaihtelevien afasiaoireistojen selittäjinä.

Servicen artikkelissa työmuisti määritellään monipuolisesti ja siinä pohditaan kliinisestä työstä erittäin tuttua vaikeutta erottaa, milloin kielellisten ohjeiden ymmärtämisen vaikeudet johtuvat työmuistikapasiteetin puutteesta ja milloin taustalla on kielijärjes- 
telmän heikkous? Työmuistin roolin pohdintaa lapsen kielen kehityksen osalta olisi voinut tiivistää. Silvola ja Lehtihalmes käsittelevät monipuolisen lähdeaineiston kautta kaksi- ja monikielistä afasiaa, joka on tärkeä ja ajankohtainen aihe. Kliinikoille työvälineeksi esitellään suomeksikin saatavilla oleva BAT-testi (Paradis, 2011), jolla voidaan arvioida kaksi- tai monikielisen henkilön kielet tasavertaisesti. Silvolan (2013) systemaattisen kirjallisuuskatsauksen pohjalta tarkastellaan yleisimmin havaittuja afasian paranemismalleja kaksi- ja monikielisillä. Korpijaakko-Huuhka ja Klippi käsittelevät ikääntymistä, viestintää ja muistisairauksia. Ikääntymismuutoksista huolimatta terveiden ikääntyneiden kielelliset kyvyt säilyvät yleensä hyvinä. Kirjoittajat nostavat selittävänä tekijänä esille Cahana-Amitayn ja Albertin (2014) katsausartikkelin tulokset, joiden mukaan ikäännyttäessä perinteisten kielellisten toimintojen ydinalueiden ulkopuoliset hermoverkot alkavat tukea kielellisiä toimintoja aiempaa enemmän. Tunnetuimpien muistisairauksien kielelliskognitiivisten ongelmien lisäksi tarkastellaan etenevien afasioiden erotusdiagnostiikka ja niiden keskeisiä piirteitä. Tämä on tärkeää, koska terminologian käyttö on vielä hyvin kirjavaa etenevien afasioiden osalta.

Klipin artikkelissa tarkastellaan vuorovaikutusta keskustelijoiden resurssien ja yhteistyön näkökulmasta. Kommunikaatiotilanteiden kontekstia ja kehollisen vuorovaikutuksen semioottisia resursseja (Streeck ym., 2011) käyttäen mukaudutaan kielelliseen häiriöön. Afasiakeskustelujen jäsentymistä ja korjaustoimintaa käsitellään esimerkkilitteraattien kautta, jotka avaavat lukijalle ilmiöitä hyvin (Klippi, 1996; Laakso, 1997). Ahlholm suosittelee käyttöpohjaista kielioppia kuntoutuksen perustaksi erittäin mielenkiintoisessa katsauksessaan siitä, miten kielen opetuksessa ja terapiassa puhetta on perinteisesti arvioitu ja verrattu kirjoitetun suomen kielen normeihin. Kirjoitettuun kieleen perustuva näkemys liikkumattomasta kielestä ei kuvaa kielen jatkuvasti puhetilanteiden pohjalta muuntuvaista kielijärjestelmää. Erityisesti minua hykerrytti hänen käyttämänsä "diskurssinallekarhu” ilmaus pehmentävän niinku -partikkelin käytöstä terapiakeskustelussa. Terapeutti turvautuu siihen varauskonstruktiona puhuessaan asiakkaan kanssa, kun ei tohdi täysin suoraan muotoilla ajatustaan sanoiksi peläten asiakkaan loukkaantuvan tai ymmärtävän väärin ammatillisen ilmaisun.

Toinen pääluku Kielihäiriöiden tutkimisen ja kuntoutuksen viitekehys keskittyy kielihäiriöiden arviointiin ja kuntoutuksen taustalla oleviin keskeisiin näkemyksiin häiriön vaikutuksista eri elämänalueilla. Johdantotekstissä kuvaillaan kovin yksityiskohtaisesti ICF-luokitusta eli tulee turhaa toistoa, koska heti sitä seuraavassa Korpijaakko-Huuhkan ja Rautakosken artikkelissa käsitellään afasiaa WHO:n (2001) julkaiseman ICF-luokituksen näkökulmasta. Malli on nykyisin paljon käytetty afasian kuvauksen ja arvioinnin sekä kuntoutuksen viitekehys. Kuntoutus kohdistuu alkuvaiheessa suoremmin kielelliseen häiriöön ja kielellisiin toimintoihin. Myöhemmin seurauskeskeisissä sosiaalisen mallin mukaisissa menetelmissä ohjataan sairastuneiden läheisiä keskustelukumppaneita, tuetaan sosiaalisen osallistumisen lisäämistä sekä pyritään muokkaamaan fyysisiä ympäristötekijöitä ja yhteiskunnallisia palvelujärjestelmiä. Koko kirja rakentuu hyvin pitkälle ICF-luokituksen mukaiseen kuntoutusnäkemykseen, mikä näkyy kuntoutusta ja arviointia käsittelevissä luvuissa punaisena lankana. Lukijalle olisi riittänyt sen tarkka esittely yhdessä kappaleessa. Muissa kuntoutukseen liittyvissä luvuissa lukija kyllä oivaltaisi luokituksen olevan kuntoutuksen taustakehikkona ilman toistuvaa siihen viittaamista. 
Akuuttia kielellistä häiriötä ja sen hoitoa käsittelevässä luvussa Soinne kuvaa selkeästi häiriöiden lääketieteellisen taustan ja erilaiset vauriomekanismit. Tärkeinä asioina esille nousevat alkuoireiden tiedostamisen merkitys ja nopea hoitoon hakeutuminen. Lehtihalmeksen ja Klipin artikkeli on kiinnostava ja tuoreista tutkimuksista koostettu kuvaus kielellisestä neuroplastisiteetista ja sen merkityksestä afasiasta toipumiselle. Afasiaterapian näkökulmasta on rohkaisevaa, että uusilla kuvantamismenetelmillä on saatu näyttöä terapian vaikuttavuudesta ja akuuttivaiheen intensiivinen kielellispainotteinen kuntoutus tukee aivojen spontaania paranemista. Klipin kirjoittama luku kommunikaatioon liittyvästä elämänlaadusta ja sen arvioimisesta on tärkeä luku kuntouttajille. Elämänlaadun kohentamiseen liittyvien tekijöiden pitäisi olla osa kuntoutusta. Sen tulisi aina perustua sairastuneen ja hänen läheistensä kanssa yhdessä asetettuihin yksilöllisiin tavoitteisiin. Puheterapeutin pitäisi löytää vahvuuksia ja resursseja perheenjäsenten välisen kommunikoinnin tukemiseksi.

Ahvenaisen ja Jäntin artikkeli on hyvä kooste kuntoutettavien työhön paluusta ja niihin vaikuttavista tekijöistä. Tutkimusten luvut työhön palaavien määristä vaihtelevat paljon ja Suomessa tutkimusta on tehty niukasti. Heidän oman tutkimuksensa (Ahvenainen \& Jäntti, 2014) mukaan kahdestakymmenestä tutkitusta kuusitoista oli työelämässä. Tutkittavat raportoivat väsymystä sekä nopeaa kuormittumista työssä ja suoriutumista heikensivät erityisesti työn suuret kielelliset vaatimukset. Kuntoutuksen pitäisi sisältää harjoitteita, jotka tukevat kuntoutujan työssä vaadittavien kielelliskognitiivisten taitojen kehittymistä ja kuntoutustyöryhmän pitäisi olla yhteydessä työnantajaan työhön paluun tai työkokeilun aikana. Työhön paluuseen liittyviä suomalaisia tutkimuksia kaivattaisiin lisää.
Kirjan kolmannessa osassa Kuntoutusmenetelmiä esitellään puheterapeuttisen kuntoutuksen menetelmiä. Kriteerinä menetelmien valinnalle toimittajat ovat pitäneet sitä, että menetelmät pohjautuvat kotimaiseen ja/tai kansainväliseen tutkimukseen. Kuntoutuksen vaikuttavuustutkimuksia puheterapiamenetelmistä tarvitaan edelleen paljon lisää (Cherney ym., 2011). On hienoa, että nimenomaan kuntoutukselle on annettu suuri painoarvo kirjassa ja kirjoittajiksi ovat lähteneet sekä itse menetelmiä kehittäneet, käyttäneet ja niitä tutkineet ihmiset. Itseoikeutetusti luvun aloittaa Leena Salonen eli suomalaisen afasiaterapian pioneeri, ja hän kuvaa kehittämänsä LET-terapian teoreettiset juuret (Vygotsky, 1962; Luria, 1973) ja menetelmän käytön yksityiskohtaisesti. Kuntoutuspolkujen konkreettinen kuvaus ja kuva-aineistojen käyttöön liittyvät ohjeet ovat todella tärkeitä menetelmän käyttäjille. Sivun 183 kuva 13.1 visualisoi loistavasti, mitä kaikkea tapahtumia sisältyy tervehdyksen toimintajärjestelmään eli kuinka paljon yksinkertainen kielelliskognitiivinen tapahtuma vaati nopeasti vaihtuvia ja toisiinsa sulautuvia osatoimintoja. Kuva kertoo pähkinänkuoressa sen, mihin ajatuksiin kuntoutusjärjestelmä perustuu.

Tuomirannan artikkeli uusien sanojen oppimisesta afasiassa on mielenkiintoinen. Hänen ja tutkimusryhmän saamat tulokset kontrolloiduista tapaustutkimuksista olivat rohkaisevia, koska kaikki afaattiset osallistujat oppivat nimeämään oikein uusia sanoja, vaihtelua oli siinä, pystyivätkö he säilyttämään oppimansa muistissa. Tärkeä huomio terapian kannalta oli, että kirjoitettuja sanoja opittiin tehokkaammin kuin kuultuja. Yhden henkilön kuvantamistutkimuksessa havaittiin oppimisen voivan tapahtua kiertoteitse hyödyntäen oikean aivopuoliskon valkean aineen ratoja. Myös Renvallin artikkeli liittyy sanaston kuntoutukseen ja siinä pohditaan kuntoutukseen valittavaa sanastoa. Nimeä- 
misen kuntoutuksen tutkimuksissa on havaittu, että kuntoutumista tapahtuu harjoiteltujen sanojen löytämisessä, mutta yleistyminen harjoitetuista sanoista muihin sanoihin tai keskusteluun on vähäistä (Nickels, 2002). Siksi sanaston valinta on keskeistä ja Renvall nostaa esille tärkeitä kysymyksiä siitä, kuka kuntoutettavan sanaston valitsee terapeutti, kuntoutettava, kuntoutettavan läheinen? Ovatko tehdyt valinnat järkeviä? Tyypillisesti harjoitellaan paljon substantiivisanastoa ja konkreettisia käsitteitä. Adjektiivisanasto ja abstraktit sanat olisivat tärkeitä tunteiden ja mielipiteiden ilmaisun kannalta. Korpusten käyttö, jotta voitaisiin valita kielessä yleisimmin käytössä olevia ilmauksia, olisi tärkeää. Valitettavasti suomen kielessä ei ole käytössä suurta puhuttua korpusta.

Leppänen tarkastelee tietotekniikkaa osana aikuisneurologista puheterapiaa, ja tämä osaalue ansaitsee ehdottomasti oman lukunsa. Tietokoneavusteisen puheterapian hyötynä on, että se mahdollistaa itsenäisen harjoittelun eli lisää sitä kautta kuntoutuksen intensiteettiä. Kirjoittaja on ilahduttavasti koonnut kuntoutuksessa käytettyjä ohjelmia lukijalle sekä Internet-sivuja, joista löytyy lisätietoa aihepiiristä. Oman kokemuksen sekä keskeisten tutkimusten kautta (esim. Zhengym., 2016) tekstissä nousee hyvin esiin puheterapeutin rooli kuntoutuksessa. Tietoteknisessä kuntoutuksessa korostuvat asiakaslähtöisyys ja terapeuttivetoisuus. Puheterapeuttien olisi myös tärkeää osallistua ohjelmistojen kehittämistyöhön, kuten kirjoittaja toteaa. Heikkinen ja Klippi tarkastelevat aivotutkimukseen perustuvia kuntoutusmenetelmiä eli afasian intensiivistä ryhmäkuntoutusta (ILAT) ja transkraniaalista magneettistimulaatiota. Menetelmillä tuetaan mahdollisimman tehokasta kielellisten verkostojen uudelleen organisoitumista aivoissa eli kuntoutus kohdistuu afaattiseen oirekuvaan. Menetelmien teoreettiset perusteet sidotaan hyvin ajankohtaiseen tutkimustietoon. ILAT pelin ohjeiden suomenkielinen esittäminen ilahduttaa varmasti monia puheterapeutteja. Transkraniaalinen magneettistimulaatio ei vielä kuulu joka terapeutin työkalupakkiin, vaan on lähinnä kokeiluasteella erikoissairaanhoidossa. Kuvatun tutkimushankkeen, jossa menetelmiä on käytetty rinnakkain, tuloksia odotetaan varmasti innostuneesti.

Korpijaakko-Huuhka tarkastelee kertomuksia afasiakuntoutuksen välineenä ja kohteena. Kerrontataitojen kuntoutus lisää afaattisen ihmisen toimintakykyä ja toisaalta sillä voidaan tukea afaattisen ihmisen ja hänen läheisensä yhdessä toteuttamaa uuden identiteetin rakentamista. Kerronnan tutkimusten ja kansainvälisten kuntoutusohjelmien kautta löytyy paljon hyviä ideoita puheterapiaa varten. Tuomenoksan artikkelissa on erittäin hyvin määritelty arkikeskustelu sekä kuvattu puheterapiakäyntiin liittyvää keskustelua. Hän esittelee keskeiset keskustelun kuntoutuksessa käytettävät menetelmät ja kuvaa hyvin läheisten ohjaamista, jotta he pystyisivät tukemaan afaattista puhujaa keskustelutilanteissa. Nämä kerronta- ja keskustelutaitoihin liittyvät menetelmät ovat seurauskeskeisiä eli häiriökeskeisestä kuntoutuksesta siirrytään näihin vähitellen. Brunoun, Klipin ja Rautakosken artikkeli jatkaa samassa aihepiirissä eli tarkastelun kohteena on afasian paripuheterapia APPUTE, joka on suomalaisen puheterapeutin kehittämä (Nykänen ym., 2013). Yksilöllisen terapian rinnalle tai jatkoksi on kehitetty menetelmä, jonka tarkoituksena on helpottaa afaattisen ihmisen ja läheisen välistä vuorovaikutusta. Menetelmä kuvataan kliinikkoja ajatellen selkeästi ja siitä saatuja tutkimustuloksia kuvataan litteraattiesimerkein. Pirkko Rautakoski kirjoittaa vaikeasti afaattisten ihmisten kommunikaatiokursseista. Niiden kehittämisestä hänellä itsellään on pitkä käytännön kokemus yhdistyneenä hänen aihepiiristä tekemäänsä tutkimukseen. 
Tässä artikkelissa tarkastellaan hyvin ryhmäkuntoutusta ja puheterapeutin roolia siinä. Kommunikaatiokurssien tavoitteena on ohjata sekä afaattisia että läheisiä saamaan kaikki mahdolliset kommunikaatiokeinot käyttöön arjessa.

Aivovammoihin liittyvät kielelliskognitiiviset häiriöt eroavat luonteeltaan afasiasta, ja siksi niistä ei käytetä afasia-termiä. Raukola-Lindblomin ja Vartiaisen kuvaavat ja määrittelevät vaativan tasoisen kielellisen prosessoinnin häiriöt sekä kieleen ja kognitiivisiin oireisiin liittyvät vuorovaikutuksen ongelmat. Kliinisen työn näkökulmasta pohditaan ansiokkaasti sekä arviointia että kuntoutusta. Taulukossa 22.1. kuvataan hyvin aivovamman jälkeisten kognitiivisten oireiden heijastumista sosiaaliseen vuorovaikutukseen Struchenin (2005) mukaan. Eri tutkimuksista kootussa taulukossa 22.2. kuvataan vuorovaikutuksen arviointiin soveltuvia menetelmiä. Terapiamenetelmien vaikuttavuusnäyttöä tarkastellaan Ciceronen ym. (2005) systemaattisen katsauksen kautta. Pekkala kirjoittaa muistisairaiden ihmisten kielen ja kommunikaation kuntoutuksesta. Ikääntyneiden määrän kasvun myötä muistisairauksiin liittyvien etenevien kielellisten häiriöiden määrä kasvaa. Suomessa muistisairaiden ihmisten puheterapiaa on niukasti saatavilla, ja virallisia hoitolinjauksia ei ole tehty. Tällainen suomenkielinen katsaus erityisesti kuntoutuksen osalta on hyvin tervetullut. Toivottavasti esitetyt myönteiset kliiniset kokemukset (Pekkala ym., 2006) auttaisivat puheterapeutteja nostamaan enemmän esille tämän ryhmän kuntoutustarpeita ja kehittämään kuntoutusmenetelmiä.

Kirjan viimeinen pääluku on nimeltään Tutkimuslinjoja ja tulevaisuuden näkymiä. Tämä luku ei ole teemoiltaan yhtä yhtenäinen kuin aiemmat. Ensimmäisenä on Klipin afasian tutkimuksen historiaa kuvaava artikkeli, joka on loistava yhteenveto eri tieteenalojen käsitysten ja tulosten kehittymisestä ajan kuluessa. Erityisen mielenkiintoista on kielitieteen ja puheterapian filosofisten perusteiden tarkastelu. Olisin mielelläni lukenut tämän artikkelin aivan kirjan alussa, koska tässä on esitetty filosofinen ja historiallinen pohja kirjan tuleville luvuille. Korpijaakko-Huuhka, Manninen ja Klippi tarkastelevat afasian kuntoutusta Suomessa suhteessa kansainvälisen asiantuntijaverkoston julkaisemiin afasian hyviin hoitokäytänteisiin (Simmons-Mackie ym., 2017). Kuntoutuksesta ei ole tehty kattavaa selvitystä, joten he tarkastelevat saatavissa olevien kartoitusten, tutkimusten ja opinnäytetöiden kyselyjen kautta, miten hoitokäytänteet toteutuvat meillä. Asialle julkisuuden saaminen ja tutkimuksen lisääminen ovat tärkeitä, koska suositukset toteutuvat valitettavan heikosti ja kuntoutuksen saatavuuden suhteen ihmiset ovat epätasa-arvoisessa asemassa. Korpijaakko-Huuhkan ja Klipin artikkelin afasiaterapian vaikuttavuustutkimuksesta olisin sijoittanut tämän pääluvun ensimmäiseksi artikkeliksi, koska se aihepiiriltään liittyy suoraan sitä ennen esiteltyihin kuntoutusmenetelmiin. Tämän jälkeen olisi sopinut hyvin kuntoutuksen toteutumista Suomessa käsittelevä luku. Kirjan päättää toimittajien yhteenvedonomainen luku monitieteisestä afasiatutkimuksesta. Kuten toimittajat toteavat ja kirjan sekä tekijöiden kirjoituksista välittyy: "Kielihäiriöiden ja niiden kuntoutuksen sekä kielen aivoperustan tutkimus sijoittuu monen tieteenalan risteyskohtaan".

Kirjan kaikille kirjoittajille ja toimittajille voi esittää suuren kiitoksen isosta urakasta, jonka tämän teoksen tekeminen on vaatinut. Erityisen tärkeänä pidän sitä, että on saatu näin kattava suomenkielinen teos, jossa terminologiaa on suomennettu ja määritelty. Suomalaisen ja kansainvälisen tutkimuksen käsittely laajan lähdeaineiston kautta sekä terapiamenetelmien kuvaaminen tekevät kirjas- 
ta houkuttelevan niin tutkijoille, kliinikoille kuin opiskelijoille. Mikä parasta, se antaa terapeutille suomenkielisiä sanoja, joilla kuvata monimutkaista ilmiötä afaattiselle henkilölle ja hänen läheisilleen. Kustantaja olisi voinut tehdä kirjan ulkoasusta paremman, kovakantisen ja sivut hieman parempilaatuisesta paperista, koska olen varma, että tämä kirja tulee kulumaan ihmisten käsissä.

\section{Terhi Hautala}

FT, yliopistonlehtori

Logopedian tutkimusyksikkö,

PL 1000, 9014 Oulun yliopisto

terhi.hautala@oulu.fi

\section{LÄHTEET}

Ahvenainen, A. \& Jäntti, H. (2014). Tutkimus aivohalvaukseen tai aivovammaan sairastuneiden puheterapiapotilaiden työhön paluusta (julkaisematon). Helsingin kaupunki, Helsinki.

Cahana-Amitay, D. \& Albert, M.L. (2014). Brain and language: Evidence for neural multifunctionality. Behavioural Neurology, 28, 1-16.

Cherney, L. R., Patterson, J. P. \& Raymer, A. M. (2011). Intensity of aphasia therapy: Evidence and efficacy. Current Neurology and Neuroscience Reports, 11, 560-569.

Cicerone, K. D., Dahlberg, C., Malec, J. F., Langenbahn, D. M., Felicetti, T., Kneipp,...Catanese, J. (2005). Evidence-based cognitive rehabilitation: Updated review of literature from 1998 through 2002. Archives of Physical Medicine and Rehabilitation, 86, 1681-1692.

Friederici, A.D. (2002). Towards a neural basis of auditory sentence processing. Trends in Cognitive Science, 6, 78-84.

Goodglass, H. \& Kaplan, E. (1972). Boston Diagnostic Aphasia Examination. Philadelphia: Lea \& Febiger.

Hagoort, P. (2013). MUC (Memory, Unification, Control) and beyond. Frontiers in Psychology, 4, Article 416.doi:10.3389/fpsyg.2013.00416.

Hickock, G. \& Poeppel, D. (2007). The cortical organization of speech processing. Nature Reviews Neuroscience, 8, 393-402.

Klippi, A. (1996). Conversation as an achievement in aphasics. Studia Fennica Linguistica 6. Hel- sinki: Suomalaisen Kirjallisuuden Seura.

Laakso, M. (1997). Self-initiated repair by fluent aphasic speakers in conversation. Studia Fennica Linguistica 8.

Luria, A. R. (1973). The working brain. An Introduction to neuropsychology. Harmondsworth: Penguin Books.

Nickels, L. (2002). Therapy for naming disorders: Revisiting, revising, and reviewing. Aphasiology, 16, 935-979.

Nykänen, A., Nyrkkö, H., Nykänen, M., Brunou, R. \& Rautakoski, P. (2013). Communication therapy for people with aphasia and their partners (APPUTE). Aphasiology, 27, 1159-1179.

Paradis, M. (2011). Principles underlying the Bilingual Aphasia Test (BAT) and its uses. Clinical Linguistics \& Phonetics, 25, 427-443.

Pekkala, S., Korhonen, M. \& Pitkänen, L. (2006). Kokemuksia dementiaa sairastavien ihmisten osallistumisesta kommunikaatioryhmän toimintaan. Teoksessa S. Simberg, P. Rautakoski, A. Klippi, J. Paloheimo \& S. Pekkala (toim.), Rybmä-ja ybteisöpohjaisen kielen ja kommunikoinnin kuntoutuksen haasteet (s. 69-75). Puheen ja kielen tutkimuksen yhdistys ry:n julkaisuja 38. Helsinki: Puheen ja kielen tutkimuksen yhdistys.

Silvola, J. (2013). Iän vaikutus kaksi- ja monikielisen afasian paranemiseen - systemaattinen kirjallisuuskatsaus. Logopedian pro gradu -tutkielma. Oulun yliopisto, Oulu.

Simmons-Mackie, N., Worral, L., Murray, L. L., Enderby, P., Rose, M.L., Paek, E. J. \& Klippi, A. (2017). The top ten: Best practice recommendations for aphasia. Aphasiology, 31, 131-151.

Streeck, J., Goodwin, C. \& LeBaron, C. (2011). Embodied interaction in the material world. Teoksessa J. Streeck, C. Goodwin \& C. LeBaron (toim.), Embodied interaction: Language and the body in the material world (s. 1-28). Cambridge: Cambridge University Press.

Struchen, M. (2005). Social communication interventions. Teoksessa W. M. High Jr., A. M. Sander, M. Struchen \& K. A. Hart (toim.), Rehabilitation for traumatic brain injury (s. 88-117). New York: Oxford University Press. Vygotsky, L. S. (1962). Thought and Language. Cambridge, MA: MIT Press. (Suomennos: Ajattelu ja kieli. Espoo: Weilin+Göös, 1982.) World Health Organization (WHO) (2001). 
ICF International Classification of Functioning, Disability and Health. Haettu osoitteesta http://www.who.int/classifications/icf/en/.
Zheng, C., Lynch, L. \& Taylor, N. (2016). Effect of computer therapy in aphasia: A Systematic review. Aphasiology, 30, 211-244. 